\title{
Do riverine barriers, history or introgression shape the genetic structuring of a common shrew (Sorex araneus) population?
}

\author{
NICOLAS LUGON-MOULIN*, HARALD BRÜNNER, FRANÇOIS BALLOUX, \\ JACQUES HAUSSER \& JÉRÔME GOUDET \\ Institut d'Ecologie, Laboratoire de Zoologie et Ecologie Animale, Bâtiment de Biologie, Université de Lausanne, \\ CH-1015 Lausanne-Dorigny, Switzerland
}

\begin{abstract}
The common shrew (Sorex araneus) is subdivided into numerous chromosome races. The Valais and Cordon chromosome races meet and hybridize at a mountain river in Les Houches (French Alps). Significant genetic structuring was recently reported among populations found on the Valais side of this hybrid zone. In this paper, a phylogenetic analysis and partial Mantel tests are used to investigate the patterns and causes of this structuring. A total of 185 shrews were trapped at 12 localities. All individuals were typed for nine microsatellite loci. Although several mountain rivers are found in the study area, riverine barriers do not have a significant influence on gene flow. Partial Mantel tests show that our result is caused by the influence of the hybrid zone with the Cordon race. The geographical patterns of this structuring are discussed in the context of the contact zone, which appears to extend up to a group of two rivers. The glacier they originate from is known to have cut the Arve valley as recently as 1818 . The recent history of this glacier, its moraine and possibly rivers, may therefore be linked to the history of this hybrid zone.
\end{abstract}

Keywords: genetic differentiation, hybrid zone, microsatellites, partial Mantel tests, phylogenetic analysis, Sorex araneus.

\section{Introduction}

Many processes and mechanisms may account for the genetic structuring of populations. Ecological (e.g. mating system, food resources) and biogeographical (e.g. mountain ridges, oceans) constraints probably affect gene flow of any species, thereby shaping patterns of population-genetic structuring. However, historical factors should not be neglected when interpreting the genetic architecture of populations. We present here a study disentangling the different causes that may be responsible for the significant genetic structuring among common shrew (Sorex araneus) populations in the French Alps that was recently reported (Lugon-Moulin et al., 1999).

Sorex araneus is a small terrestrial mammal that is subdivided into numerous chromosome races (Zima et al., 1996). The majority of interracial hybrid zones in this species have been studied using karyotypic data, although proteins (e.g. Brünner \& Hausser, 1996) and,

*Correspondence. E-mail: nicolas.lugon-moulin@ie-zea.unil.ch (C) 1999 The Genetical Society of Great Britain. more recently, microsatellites (Lugon-Moulin et al., 1996, 1999; Wyttenbach et al., 1999) have also been used. Near Chamonix, in the French Alps, the Valais and the Cordon chromosome races meet and hybridize at a mountain river, the Torrent de la Griaz (e.g. Brünner \& Hausser, 1996). This is revealed by the very abrupt step in frequencies of the chromosomes, albumins and urinary pepsins characteristic for each race (Brünner \& Hausser, 1996). Indeed, these two chromosome races possess different karyotypes (Hausser et al., 1991) and different fixed alleles at both the albumin and urinary pepsin loci (Neet \& Hausser, 1991).

A preliminary study using microsatellites detected significant structuring across this hybrid zone (LugonMoulin et al., 1996). Using partial Mantel tests, it was shown that this result reflected the differentiation of the two races, but rivers were not found to affect gene flow significantly (Lugon-Moulin et al., 1996). Using an extended sample consisting of additional collecting sites, Lugon-Moulin et al. (1999) compared the efficiency of $F$ - and $R$-statistics to detect genetic structuring both at the inter- and intraracial levels. Using exact $G$-tests (Goudet et al., 1996), they reported a significant genetic 


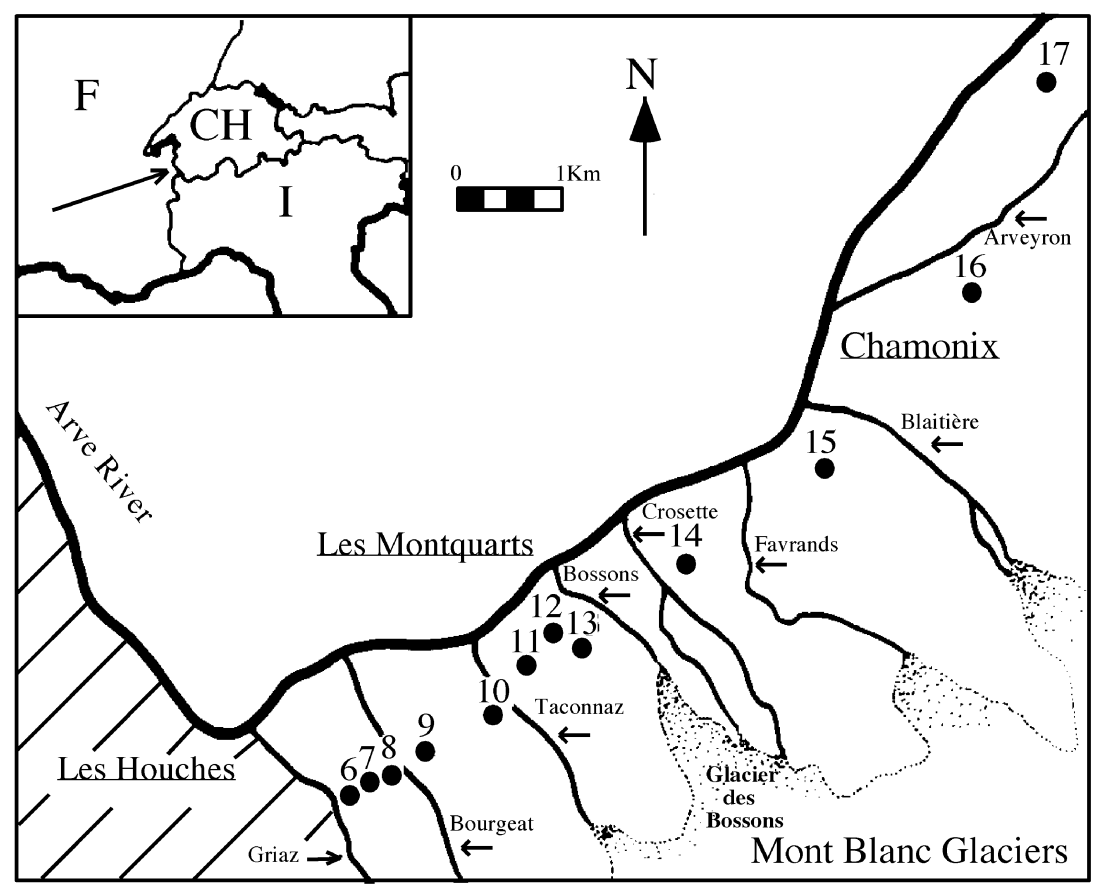

Fig. 1 Map of the study area representing the sampling sites of the Valais chromosome race of Sorex araneus (closed circles, 6-17). At Les Houches, the Valais race is sharply replaced after a river, the Torrent de la Griaz (Griaz), by another chromosome race, the Cordon race, occurring in the hatched part. Missing sites (i.e. sites 1-5) are located on the Cordon side of the hybrid zone (i.e. to the west of the Torrent de la Griaz) and are not included in this study. The bold line represents the Arve River and the fine lines represent mountain rivers originating from the Mont Blanc glaciers.

structuring on the Valais side of the hybrid zone (i.e. eastwards of the Torrent de la Griaz). However, the causes of this structuring were not investigated.

Because the additional samples from the easternmost localities are separated from each other by rivers, riverine barriers could be major contributors to this within-race genetic structuring. Indeed, in some taxa, rivers form an effective barrier to dispersal. For example, the major tributaries of the Amazon river act as barriers to the dispersal of saddle-back tamarins ( Saguinus fuscicollis) (Peres et al., 1996). In other taxa, however, even major rivers do not appear to reduce current gene flow in small mammals. For example, the Jurua river in the Amazon basin does not reduce gene flow in the arboreal spiny rat (Mesomys spp.) (Patton et al., 1994). However, other factors may also be invoked in the present case. For instance, the glacier des Bossons is known to have cut the Arve valley as recently as 1818 (Mougin, 1909, 1910). Today, this glacier is still quite close to the trapping area and has an impressive moraine. Therefore, the recent history of this glacier, and its associated moraine and rivers, may have shaped the genetic architecture of these Valais shrew populations. Finally, the presence of the hybrid zone may also account for this significant population structuring. Indeed, although inter-racial gene flow is clearly reduced (Lugon-Moulin et al., 1999), successful interracial matings occur, as shown both by the finding of karyotypic hybrids on both sides of the hybrid zone (Brünner \& Hausser, 1996) and successful laboratory crossings (Castagné et al., 1994).
Therefore, several causes may be responsible for the significant genetic structuring reported by LugonMoulin et al. (1999). However, these causes remain to be elucidated. The primary aim of this paper is therefore to clarify the geographical pattern of this structuring and identify its causes. To address these questions, rapidly evolving genetic markers, namely microsatellites, are used. These markers show high mutation rates making them useful in studying relationships and divergence among geographically proximate populations (Jarne \& Lagoda, 1996).

\section{Materials and methods}

\section{Sampling}

From 1992 to 1995, 185 individuals were collected with Longworth traps at or near the Les Houches hybrid zone (Haute-Savoie, France; Brünner \& Hausser, 1996), to the east of the Torrent de la Griaz, hereafter named the Valais side (Fig. 1; Table 1). Trapping was carried out along a roughly $10 \mathrm{~km}$ transect at 12 different sites (Fig. 1). Sites were numbered from 6 to 17, following previous studies on this hybrid zone (Brünner \& Hausser, 1996; Lugon-Moulin et al., 1996, 1999). Missing sites (i.e. sites 1-5) are located on the Cordon side of the hybrid zone (i.e. to the west of the Torrent de la Griaz) and are not included in this study. Most sites were not sampled in all years. DNA sampling was performed by toe-clipping and shrews were released at their collecting site. Total genomic DNA was isolated 
Table 1 Number of individuals of Sorex araneus collected per trapping locality (6-17) over the four pooled years 1992-95

\begin{tabular}{llc}
\hline No. & \multicolumn{1}{c}{ Trapping locality } & Total (1992-95) \\
\hline 6 & Granges des Faux I & 27 \\
7 & Granges des Faux II & 26 \\
8 & Granges des Faux III & 36 \\
9 & Le Trembley & 21 \\
10 & Taconnaz & 9 \\
11 & Vers le Nant & 12 \\
12 & Les Granges & 4 \\
13 & Les Tissières & 15 \\
14 & Chalet J. Balmas & 14 \\
15 & Chamonix Téléphérique & 4 \\
16 & Les Coverays & 7 \\
17 & Les Tines & 10 \\
Total & & 185 \\
\hline
\end{tabular}

Site numbers follow Brünner \& Hausser (1996) and LugonMoulin et al. (1996, 1999). Sites 1-5 are located on the Cordon side and are not included in the present study (see text).

from ethanol-preserved phalanxes as described in Lugon-Moulin et al. (1999).

The Valais side is characterized by several mountain rivers, all originating from the Mont Blanc glaciers (Fig. 1). The Torrent du Bourgeat and the Torrent des Taconnaz are fairly large rivers with rocky beds. The Torrent des Bossons and the Torrent de la Crosette both originate from the glacier des Bossons (Fig. 1). The upper bed of the former lies in an impressive moraine, but it becomes narrow further down, whereas the latter river possesses a stony bed up to about $20 \mathrm{~m}$ wide, with large rocky edges, even down in the Arve valley. Further to the east, two smaller rivers are found, the Torrent des Favrands and the Torrent de Blaitière, the latter being quite small in comparison to the other rivers. Throughout its length its bed is shallow and much narrower than the others. Finally, the Arveyron river, originating from the Mer de Glace, is a large river like the Torrent de la Crosette. Most of these rivers are bordered by manmade protection walls in their lower courses to counteract flooding from the frequent bursts of water coming from the glacier. The water levels and currents are variable along the courses of the rivers and also depend on the season.

\section{Microsatellite DNA}

Nine loci $[L 9, L 45, L 57, L 62, L 67, L 69$ (Wyttenbach et al., 1997) and L33, L68, L14 (Balloux et al., 1998)] were used for analysis. Amplification conditions are described in Lugon-Moulin et al. (1999) and Balloux et al. (1998). All samples were electrophoresed on a denaturing polyacrylamide gel $(6 \%, 8 \mathrm{~m}$ urea). Fixation, drying and autoradiography followed standard procedures (Sambrook et al., 1989). A sequencing reaction and a clone of known size were run with the samples as size markers.

\section{Temporal variability of microsatellites}

Because most samples were collected in more than one year (see Lugon-Moulin et al., 1999 for the yearly sample sizes), we tested whether there was genetic structuring over years for the same collecting site (e.g. genetic drift, extinction and recolonization; Viard et al., 1997). If not, samples from the same site, but obtained on a different date, can be pooled together to increase sample size.

Therefore, temporal variation in allele frequencies for sites where samples were obtained in different years (i.e. sites 6, 7, 8, 9, 13 and 14; Lugon-Moulin et al., 1999) was investigated using the exact $G$-test advocated by Goudet et al. (1996). When carried out on genic tables, this was shown to be the most powerful test for genetic differentiation, particularly when samples are unbalanced (Goudet et al., 1996), as is the case here. A total of 5000 permutations of genotypes among samples were performed to assess the significance of the temporal differentiation. Computations were performed using FSTAT 2.7, updated from Goudet (1995). Significance over all sites was obtained by using the PG-test advocated by Goudet (1999). Goudet (1999) showed that when a distribution of $P$-values is symmetrical around 0.5 , but U-shaped, Fisher's procedure (Sokal \& Rohlf, 1995) gives unduly large type I errors, whereas it is too conservative when the distribution is bell-shaped. The PG-test removes these caveats.

\section{Evolutionary relationships among samples}

We used Cavalli-Sforza and Edwards chord distances (Cavalli-Sforza \& Edwards, 1967) to reconstruct evolutionary relationships between our samples. This Euclidean distance was shown to be the most efficient measure out of seven distances compared in reconstructing trees when heterozygosities are high (Takezaki \& Nei, 1996), as will be the case in analyses of populations with highly variable markers such as microsatellites. In particular, this distance outperformed distances designed for the stepwise mutation model (Takezaki \& Nei, 1996). Genetic distances were calculated from allele frequencies using the phylogenetic package PHYLIP 3.57c (Felsenstein, 1995). A neighbourjoining tree, which allows for different evolutionary rates in the different populations, was constructed (Saitou \& Nei, 1987). The tree was rooted using individuals of the Cordon race from samples 1 and 2 in 
Brünner \& Hausser (1996). This race is well differentiated from the Valais race (e.g. Hausser et al., 1991; Lugon-Moulin et al., 1999). The input order of species was randomized to ensure that the final tree topology was not dependent on the order the samples are entered (option $\mathbf{J}$ in NeIGHBOUR). Robustness of each node was evaluated by bootstrapping gene frequencies 1000 times (SEQBOOT subroutine in PHYLIP).

\section{Mantel tests}

Mantel tests (Manly, 1991, 1997) were used to test for different factors that may account for the significant structuring detected on the Valais side by Lugon-Moulin et al. (1999). Matrices were therefore created for the possible causes of this genetic structuring. The effect of isolation by distance and the effect of rivers on genetic distances were investigated. The river matrix, called river1, contains values corresponding to the number of rivers separating the samples. A 'Bossons' matrix was created to account for a possible effect of the glacier des Bossons, and its associated moraine and rivers. This third independent matrix contains 1 if the samples are separated by the Torrents des Bossons and de la Crosette, and 0 if they are not (these two rivers originate from the glacier des Bossons). Finally, to test whether the hybrid zone accounts for the significant genetic structuring previously reported, a matrix considering the degree of hybridization of the samples was created using the diagnostic markers (albumins and urinary pepsins) analysed by Brünner \& Hausser (1996). Nei's unbiased (1978) genetic distances were calculated from albumin and urinary pepsin allele frequencies (Brünner \& Hausser, 1996; H. Brünner, unpubl. results). The resulting distance matrix, called the 'hybrid' matrix, is therefore based solely on diagnostic markers for the two races, and thus reflects the degree of hybridization of the samples.

Because sampling was performed along a transect, the various independent matrices (river, geographical distance, Bossons and hybrid matrices) are likely to be themselves correlated. Therefore, to eliminate potentially spurious correlations, multiple matrices partial Mantel tests (Manly, 1997) were performed. To test the effect of the Bossons matrix once the effect of rivers is accounted for, and conversely, a new river matrix (river2) similar to the original one (river1 matrix), but omitting the Torrents des Bossons and de la Crosette, was created.

Mantel tests for more than two matrices were considered by Smouse et al. (1986) and Manly (1986). Partial Mantel tests enable us to assess how much additional information is provided by the addition of a matrix, given that another has already been included in the analysis. Their usage is now frequent in evolutionary biology and
Table 2 Results of the partial Mantel tests

\begin{tabular}{lcc}
\hline Matrices compared & $\begin{array}{c}\text { Extra } \\
\text { variance explained }\end{array}$ & $P$ \\
\hline Gendist. river1. geo & 0.0000 & 0.9924 \\
Gendist. Bossons. geo & 0.0022 & 0.8501 \\
Gendist. hybrid. geo & 0.1748 & 0.0332 \\
Gendist. geo. river1 & 0.0155 & 0.4695 \\
Gendist. Bossons. river2 & 0.0000 & 0.9622 \\
Gendist. hybrid. river1 & 0.1903 & 0.0068 \\
Gendist. geo. Bossons & 0.1018 & 0.0435 \\
Gendist. river2. Bossons & 0.1858 & $0.0021^{*}$ \\
Gendist. hybrid. Bossons & 0.2235 & $0.0020^{*}$ \\
Gendist. geo. hybrid & 0.3451 & $0.0001^{*}$ \\
Gendist. river1. hybrid & 0.3451 & $0.0001^{*}$ \\
Gendist. Bossons. hybrid & 0.2942 & $0.0002^{*}$ \\
\hline
\end{tabular}

$\mathrm{X}$. Y. Z gives the amount of variance of $\mathrm{X}$ explained by $\mathrm{Z}$ once $\mathrm{Y}$ is taken into account, and $P$ is the probability that this variance is different from zero. Asterisks $(*)$ indicate significant $P$-values at the Bonferroni-corrected alpha probability level $(P=0.0042)$. Gendist $=$ genetic distances matrix; geo $=$ matrix of geographical distances; river1 and river2 = river1 and river2 matrices, respectively; Bossons $=$ Bossons area matrix; hybrid is a matrix indicating the degree of hybridization (see text for explanation of the matrices).

ecology (e.g. Daltry et al., 1996; Thorpe, 1996; Knoll \& Rowell-Rahier, 1998; and references therein). The program used was a Pascal translation of the FORTRAN code found in Manly (1991). It is available free from J. Goudet. A total of 10000 randomizations on rows and columns of the distance matrix to be explained were carried out to test whether the amount of variance explained by the addition of a second explanatory distance matrix (once the first has been accounted for) significantly differs from zero. To reduce the likelihood of type I errors among the 12 partial Mantel tests (see Table 2), a Bonferroni correction (Sokal \& Rohlf, 1995) was applied, setting the (Bonferroni-corrected) probability level to $P=0.0042(0.05 / 12)$.

\section{Results}

\section{Temporal variability of microsatellites}

Out of the six sampling sites tested for temporal variation in allele frequencies, only site 8 showed significant overall loci differentiation (exact $G$-test, $P=0.04$ ). However, when combining probabilities across sites, the change is not significant (PG-test, $P>0.1)$. We therefore pooled samples from the same site over years. Each sampling site consists now of a single sample (Table 1). Details of the yearly sample sizes are given by Lugon-Moulin et al. (1999). 


\section{Evolutionary relationships among samples}

The consensus tree revealed two major groupings supported by high bootstrap values ( $>70 \%$; Fig. 2). A first assemblage consists of samples 6,7 and 8 (bootstrap value: $77 \%$ ), the first two (i.e. samples 6 and 7) being joined in $81 \%$ of the resampled trees (Fig. 2). These three samples are physically close to each other and lie between the Torrent de la Griaz (representing the meeting point with the Cordon race) and the Torrent du Bourgeat (Fig. 1). The second assemblage consists of samples 14-17, which form a distinct cluster supported by a bootstrap value of $72 \%$. This sample assemblage is separated from other samples by the Torrents des Bossons and de la Crosette (Fig. 1). The tree topology among samples $14-17$ is however, poorly resolved. The remaining samples on the dendrogram show low bootstrap support (Fig. 2).

\section{Mantel tests}

Because the geographical distance and the river matrices (river1) are strongly correlated $(r=0.90, P=0.0001)$, standard Mantel tests are meaningless. Thus, only partial Mantel tests are presented here.

Partial Mantel tests indicate that only the hybrid matrix is meaningful (Table 2). Whichever matrix is accounted for, the hybrid distance matrix remains significantly correlated with the matrix of microsatellite-derived genetic distances. Partial Mantel tests indi- cate that neither the geographical distance nor the effect of rivers is significant (Table 2). The Bossons matrix is no longer significant at the Bonferroni-corrected probability level when the geographical distances matrix is accounted for $(P=0.04$; Table 2$)$.

\section{Discussion}

Recently, Lugon-Moulin et al. (1999) reported a significant genetic structuring among shrew populations found on the Valais side of the Les Houches hybrid zone $\left(F_{\mathrm{ST}}=0.022 ; P<0.0002\right)$. However, neither the geographical pattern nor the causes of this structuring were investigated. These questions are addressed here.

\section{Geographical patterns and causes of structuring}

Samples 6-8 and 14-17 form two well-supported clusters, whereas samples 9-13 do not form any wellsupported assemblages. Because partial Mantel tests show a significant correlation between microsatellitederived genetic distances among samples and the degree of hybridization of the samples, we interpret the results of the phylogenetic analysis as introgression patterns.

Samples 6-8 represent the westernmost Valais samples, separated from the Cordon race only by the Torrent de la Griaz (see Fig. 1). This well-supported group of samples should therefore lie in the centre of the hybrid zone, as is also suggested by their geographical location. Samples 14-17, all found to the east of the
Fig. 2 Consensus tree based on CavalliSforza \& Edwards (1967) chord distances derived from allele frequencies at nine microsatellite loci (neighbour-joining method of tree reconstruction). The Cordon chromosome race (Cordon) was used as an outgroup. Numbers at the nodes indicate the percentage of 1000 bootstrap replicates $(>50 \%)$ that supported the node. Branches not supported by bootstrap values of at least $50 \%$ were collapsed. 'VS' stands for the Valais chromosome race.

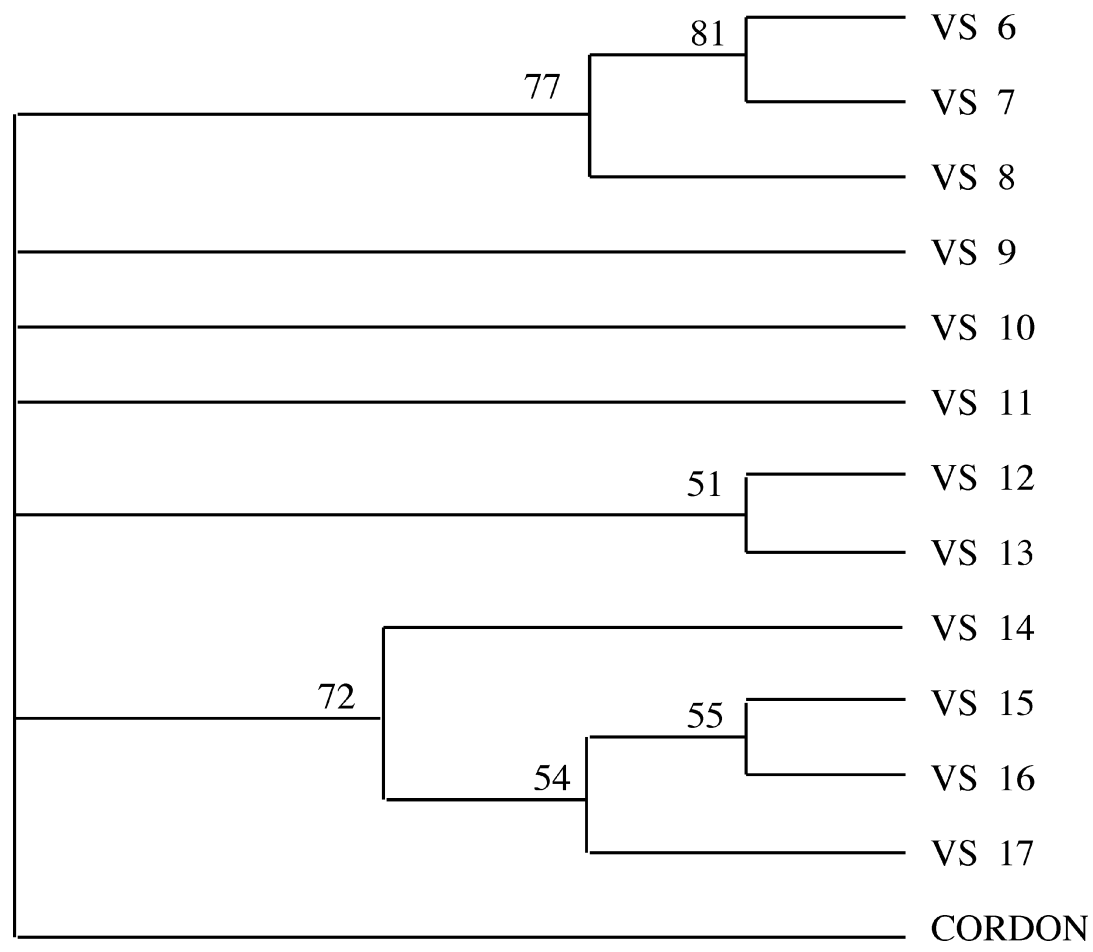


Torrents des Bossons and de la Crosette, form the second well-supported cluster. Therefore, these samples are differentiated from the others and should lie in a region where introgression from the Cordon race is weak (samples 9-13 are situated in between).

This interpretation is supported by Brünner \& Hausser's (1996) results, as introgression in samples 14-17 is either absent according to chromosomes and urinary pepsins, or weak according to albumins. Indeed, karyotypic hybrids were found in samples 6-11 (Brünner \& Hausser, 1996). They may have been missed in sample 12, which consists only of four individuals. Introgression of urinary pepsins extends up to sample 13, and albumin introgression can be detected up to sample 17 (frequency of the Valais diagnostic allele in samples 16 and 17: $f=0.955$ and 0.900 , respectively; Brünner \& Hausser, 1996).

\section{A possible role of the glacier des Bossons}

Microsatellite analysis, as well as chromosome and protein frequency data, suggest that introgression is much weaker in samples 14-17. Interestingly, this corresponds to the area to the east of the Torrents des Bossons and de la Crosette. Moreover, partial Mantel tests suggest an additional slight genetic break at this location (Bossons matrix; see Results). It is therefore possible that the history of the glacier des Bossons, its moraine and rivers, played a role in the recent history of this hybrid zone. Indeed, this glacier is known to have reached the bottom of the valley in the recent past and its recent length variations are well established (Mougin, 1909, 1910). In 1774 it invaded cultivated land, and two years later its progression had continued (Bourrit, 1776; Coxe, 1781, 1790; all cited in Mougin, 1910). In 1812 a period of six cold winters began and the glacier progressed again. It reached its maximum in 1818, when it threatened the village of Les Montquarts and destroyed 4-5 ha of cultivated land and a forest (Mougin, 1909, 1910). The frightened villagers walked in procession to the glacier and set a cross on the front of the moraine, as before in 1643/44. From 1818, the glacier slowly retreated (Mougin, 1909), leaving a very deep and large moraine in front of it. In 1835, the ice still almost reached the road leading to Chamonix (Mougin, 1910). By cutting the Arve valley, it may have limited genetic introgression from the Cordon race further to the east, and also promoted the differentiation of opposite-bank populations. Such temporary isolation of $S$. araneus populations by this glacier may have been frequent since the end of the last Pleistocene glaciations, although it is not possible to assess the frequency of such events in the more distant past. After the latest glacier retreats, extensive gene flow was probably not possible, principally because of the large moraine, extending rather far down the valley. Moreover, prior to the advent of effective flood control, the Torrent des Bossons was subject to intense flooding caused by the melt-off from the glacier, as attested by the major floods reported in 1905 and 1906 (Kinzl, 1932). A contribution of the Torrents des Bossons and de la Crosette is therefore also possible.

\section{The effect of rivers}

Mountain rivers (except maybe the rivers of the Bossons area) in the Arve valley represent only weak to moderate barriers to shrew dispersal. This result agrees with the preliminary study on gene flow in this hybrid zone (Lugon-Moulin et al., 1996), and is not contradicted by the contact between the Valais and Cordon races being at a rather large river, the Torrent de la Griaz. This river is not an impassable obstacle, as shown by the presence of an individual found on the 'wrong' side of the contact zone (Brünner \& Hausser, 1996), but its effect seems sufficient to trap the hybrid zone at this location. Indeed, tension zones (i.e. hybrid zones maintained by a balance between dispersal and selection; Barton \& Hewitt, 1985) can move from place to place and tend to come to rest in regions of low population density or at local geographical barriers (Hewitt, 1988).

\section{Conclusion}

Using microsatellites, we have shown that the significant structuring of $S$. araneus populations on the Valais side of the Les Houches hybrid zone reflects introgression patterns arising from the hybrid zone. The high polymorphism of these markers has enabled us to unravel the fine-scale geographical patterns of this genetic structuring. The present work shows the potential utility of microsatellites in the study of introgression in hybrid zones. Its application to empirical investigations in other hybrid zones should show the efficiency of these markers in studying evolutionary processes during hybridization of genetically differentiated populations.

\section{Acknowledgements}

We are extremely grateful to John Aeschimann, Hedy Brack, Cédric Cretegny, Christian Koenig, Patrick Patthey, Andrea Persico and Hendrik Turni for their invaluable help in the field; Nelly Di Marco for technical assistance; Vincent Castella, Manuel Ruedi and two anonymous referees for helpful comments on a previous version of the manuscript. This work was supported by the Swiss National Science Foundation (grant no. 3134057.92 to J.H.), by a grant of the French Embassy in 
Switzerland to J.H. and grants to J.G. (nos 31-43443.95 and 31-55945.98).

\section{References}

BALLOUX, F., ECCOFEY, E., FUMAGALli, L., GOUDET, J., WYTTENBACH, A. AND HAUSSER, J. 1998. Microsatellite conservation, polymorphism, and GC content in shrews of the genus Sorex (Insectivora, Mammalia). Mol. Biol. Evol., 15, 473-475.

BARTON, N. H. AND HEWITT, G. M. 1985. Analysis of hybrid zones. Ann. Rev. Ecol. Syst., 16, 113-148.

BRÜNNER, H. AND HAUSSER, J. 1996. Genetic and karyotypic structure of a hybrid zone between the chromosomal races Cordon and Valais in the common shrew, Sorex araneus. Hereditas, 125, 147-158.

CASTAGNÉ, C., MEHMETI, A.-M. AND HAUSSER, J. 1994. Interbreedings between karyotypic Alpine races of the common shrew Sorex araneus (Insectivora, Mammalia). Caryologia, 47, 11-18.

CAVAlli-SFORZA, L. L. AND EDWARdS, A. W. F. 1967. Phylogenetic analysis: models and estimation procedures. Am. J. Hum. Genet., 19, 233-257.

DAlTRY, J. C., WÜSTER, W. AND THORPE, R. S. 1996. Diet and snake venom evolution. Nature, 379, 537-540.

FElsENSTEIN, J. 1995. PHYLIP. Phylogeny inference package, Version 3.57c. University of Washington, Seattle.

GOUDET, J. 1995. FSTAT, Version 1.2: a computer program to calculate $F$-statistics. J. Hered., 86, 485-486.

GOUDET, J. 1999. An improved procedure for testing the effects of key innovations on rate of speciation. Am. Nat., 153, 549555.

GOUDET, J., RAYMOND, M., DEMEEÜS, T. AND ROUSSET, F. 1996. Testing genetic differentiation in diploid populations. Genetics, 144, 1933-1940.

HAUSSER, J., BOSSHARD, E., TABERLET, P. AND WOJCIK, J. 1991. Relationship between chromosome races and species of the Sorex of the araneus group in the western Alps. Mém. Soc. Vaud Sc. Nat., 19, 79-95.

HEWITT, G. M. 1988. Hybrid zones - Natural laboratories for evolutionary studies. Trends Ecol. Evol., 3, 158-167.

JARNE, P. AND LAGODA, P. J. L. 1996. Microsatellites, from molecules to populations and back. Trends Ecol. Evol., 11, 424-429.

KINZL, H. 1932. Die grössten nacheiszeitlichen Gletschervorstösse in den Schweizer Alpen und in der Mont BlancGruppe. Z. Glkde., 4/5, 269-397.

KNOLL, S. AND ROWELL-RAHIER, M. 1998. Distribution of genetic variance and isolation by distance in two leaf beetle species: Oreina cacaliae and Oreina speciosissima. Heredity, 81, 412421.

LUGON-MOULIN, N., WYTTENBACH, A., BRÜNNER, H., GOUDET, J. AND HAUSSER, J. 1996. Study of gene flow through a hybrid zone in the common shrew (Sorex araneus) using microsatellites. Hereditas, 125, 159-168.

LUGON-MOULIN, N., BRÜNNER, H., WYTTENBACH, A., HAUSSER, J. AND GOUDET, J. 1999. Hierarchical analyses of genetic differentiation in a hybrid zone of Sorex araneus (Insectivora, Soricidae). Mol. Ecol., 8, 419-432.
MANLY, B. F. J. 1986. Randomization and regression methods for testing associations with geographical, environmental and biological distances between populations. Res. Pop. Ecol., 28, 201-218.

MANLY, B. F. J. 1991. Randomization and Monte Carlo Methods in Biology, 1st edn. Chapman \& Hall, London.

MANLY, B. F. J. 1997. Randomization, Bootstrap and Monte Carlo Methods in Biology, 2nd edn. Chapman \& Hall, London.

Mougin, P. 1909. Les variations de longueur du glacier des Bossons (vallée de Chamonix) de 1818 à 1904. Z. Glkde, 3/2, 144-148.

Mougin, P. 1910. Etudes glaciologiques. Savoie. Programme pour l'étude d'un grand glacier. Serv. Gr. Forces Hydraul., 2, $1-15$.

NEET, C. R. AND HAUSSER, J. 1991. Biochemical analysis and determination of living individuals of the Alpine karyotypic races and species of the Sorex araneus group. Mém. Soc. Vaud. Sc. Nat., 19, 97-106.

NEI, M. 1978. Estimation of average heterozygosity and genetic distance from a small number of individuals. Genetics, $\mathbf{8 9}$, 583-590.

PATTON, J. L., DA SILVA, M. N. F. AND MALCOLM, J. R. 1994. Gene genealogy and differentiation among spiny rats (Rodentia: Echimyidae) of the Amazon basin: a test of the riverine barrier hypothesis. Evolution, 48, 1314-1323.

PERES, C. A., PATTON, J. L. AND DA SILVA, M. N. F. 1996. Riverine barriers and gene flow in Amazonian saddle-back tamarins. Folia Primatol., 67, 113-124.

SAITOU, N. AND NEI, M. 1987. The neighbor-joining method: a new method for reconstructing phylogenetic trees. Mol. Biol. Evol., 4, 406-425.

SAMBROOK, J., FRITSCH, E. F. AND MANIATIS, T. 1989. Molecular Cloning, 2nd edn. Cold Spring Harbor Laboratory Press, Cold Spring Harbor, New York.

SMOUSE, P. E., LONG, J. C. AND SOKAL, R. R. 1986. Multiple regression and correlation extensions of the Mantel test of matrix correspondence. Syst. Zool., 35, 627-632.

SOKAL, R. R. AND ROHLF, F. J. 1995. Biometry, 3rd edn. Freeman, San Francisco.

TAKEZAKI, N. AND NEI, M. 1996. Genetic distances and reconstruction of phylogenetic trees from microsatellite DNA. Genetics, 144, 389-399.

THORPE, R. S. 1996. The use of DNA divergence to help determine the correlates of evolution of morphological characters. Evolution, 50, 524-531.

VIARD, F., JUSTY, F. AND JARNE, P. 1997. Population dynamics inferred from temporal variation at microsatellite loci in the selfing snail Bulinus truncatus. Genetics, 146, 973-982.

WYTTENBACH, A., FAVRe, L. AND HAUSSER, J. 1997. Characterization of simple sequence repeats in the genome of the common shrew. Mol. Ecol., 6, 797-800.

WYTTENBACH, A., NARAIN, Y. AND FREDGA, K. 1999. Genetic structuring and gene flow in a hybrid zone between two chromosome races of the common shrew (Sorex araneus, Insectivora) revealed by microsatellites. Heredity, 82, 79-88.

ZIMA, J., FEDYK, S., FREDGA, K., HAUSSER, J., MISHTA, A., SEARLE, J. B. ET AL. 1996. The list of the chromosome races of the common shrew (Sorex araneus). Hereditas, 125, 97 107. 